\title{
JAPONIA
}

Barbara Mrówka

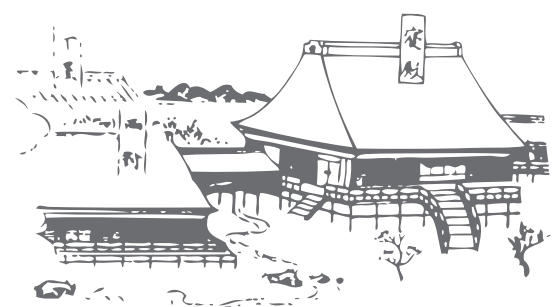

\section{ZAKOŃCZENIE MISJI JAPOŃSKICH SPECJALISTÓW W POLSCE. DOŚWIADCZENIA PIERWSZEGO ETAPU WSPÓŁPRACY POMOCOWEJ}

\section{Charakterystyka japońskiej pomocy rozwojowej}

Japońska pomoc zagraniczna bierze swoje początki z reparacji wojennych, które rząd Japonii zobowiązany był wypłacić po zakończeniu II wojny światowej. 13 krajów azjatyckich było uprawnionych do otrzymania rekompensat na poziomie wynegocjowanym indywidualnie z rządem Japonii. Wypłata tych zobowiązań zakończyła się w 1977 r. i obliczona została na łączną kwotę ok. 2 mld USD ${ }^{1}$. Należne w ramach reparacji środki zostały przeznaczane na finansowanie projektów zgłaszanych przez rządy uprawnionych krajów. Zgodnie z procedurą występowały one z formalnym wnioskiem do Tokio i po uznaniu działań za wykonalne można było przystapić do ich realizacji. W rzeczywistości to japońskie firmy w krajach rozwijających się często same inicjowały projekty i przedkładały je rządom krajów rozwijających się jako inicjatywy do sfinansowania w ramach wsparcia japońskiego. Te same firmy stawały się później wykonawcami zatwierdzonych do realizacji projektów.

Do końca lat 90. pomoc japońska kształtowana była głównie przez trzech aktorów: biurokrację różnych ministerstw, decydującą o wielkości, dystrybucji i wykorzystaniu pomocy; biznes - szczególnie przedsiębiorstwa budowlane, inżynieryjne i firmy konsultingowe wdrażające większość pomocy, oraz rządzącą Partię Liberalno-Demokratyczną (Liberal Democratic Party, LDP), politycznie wspierającą działania pomocowe bez większej ingerencji w szczegóły działań. W Japonii, ina-

\footnotetext{
${ }^{1}$ Carol Lancaster, Foreign Aid, Chicago and London 2007, s. 112.
} 
czej niż w Europie czy w Stanach Zjednoczonych, aż do końca XX w. niewielką rolę w działaniach pomocowych odgrywały japońskie organizacje pozarządowe (Non-governmental Organizations, NGOs), zarówno jako organizacje wdrażające, jaki i pełniące rolę rzecznika działań pomocowych na rzecz rozwoju. Cele pomocy określała już sama jej organizacja. Kluczową rolę w procesach decyzyjnych odgrywały przede wszystkim Ministerstwo Spraw Zagranicznych, Ministerstwo Finansów oraz Ministerstwo Handlu i Przemysłu (później Ministerstwo Gospodarki, Handlu i Przemysłu). Formalnie wpływ na działania pomocowe miały również dwie pararządowe agencje - Zagraniczny Fundusz Współpracy Ekonomicznej (Overseas Economic Cooperation Fund, OECF), który później stał się częścią Japońskiego Banku Współpracy Gospodarczej (Japan Bank for International Cooperation, JBIC), i Japońska Agencja Współpracy Międzynarodowej (Japan International Cooperation Agency, $\mathrm{JICA}^{2}$ ), wdrażające działania pomocowe.

Japońska pomoc rozwojowa (Official Development Assistance, ODA) obejmuje trzy filary: pożyczki bilateralne, współpracę techniczną oraz pomoc grantową. Początkowo większość działań realizowana była w formie pożyczek udzielanych w jenach. Pomoc japońska w postaci grantów datuje się od 1968 r., kiedy po raz pierwszy, w rezultacie rundy negocjacyjnej GATT, rząd Japonii przekazał pomoc żywnościową w ramach Międzynarodowego Porozumienia w sprawie Zbóż. W 1969 r. przygotowany został pierwszy grant ogólny i rozpoczęto działania finansowane z japońskiej bezzwrotnej pomocy zagranicznej. Udział grantów w całości pomocy japońskiej stopniowo się zwiększal, choć wciąż pozostaje poniżej średniego poziomu ustalonego przez Komitet Pomocy Rozwojowej (Development Assistance Committee, DAC) ${ }^{3}$. Głównymi priorytetami pomocy japońskiej aż do końca lat 90. były nie działania pomocowe w rozumieniu OECD (ujmując rzecz bardzo skrótowo, walka z biedą i zrównoważony rozwój), ale przede wszystkim korzyści w sferze handlu oraz cele dyplomatyczne. Główny nacisk w działaniach pomocowych położony został na kraje azjatyckie i na sektory atrakcyjne dla eksporterów japońskich. Celem rządu Japonii był szybki wzrost eksportu oraz otwarcie dostę-

2 Japońska organizacja rządowa powstała w 1974 r., wspierająca kraje rozwijające poprzez dostarczanie wiedzy technicznej, rozwiązań organizacyjnych oraz ekspertów. JICA obecna była w naszym kraju do 2007 r. W ramach jej oferty wspierano m.in. budowanie instytucji oraz kształcenie nowych kadr dla gospodarki (hitozukuri). Od 1990 r. wyjechało do Japonii na szkolenia 784 specjalistów z Polski. Mieli oni możliwość dokształcania się w takich dziedzinach, jak m. in.: produktywność, zarządzanie jakością, ochrona środowiska, agrobiznes, telekomunikacja. W tym samym czasie do Polski przyjechało 256 ekspertów japońskich, którzy pracowali w instytucjach rządowych, ośrodkach naukowych, edukacyjnych i szkoleniowych itp.

3 Organ Organizacji Współpracy Gospodarczej i Rozwoju (OECD), powołany w celu koordynowania pomocy udzielanej przez państwa członkowskie OECD krajom rozwijającym się oraz krajom w okresie transformacji. 
pu do surowców w krajach terytorialnie bliskich. Pomoc miała więc za cel odbudowanie dobrych relacji z państwami regionu oraz przywrócenie Japonii pozycji szanowanego członka społeczności międzynarodowej. Była postrzegana mniej jako instrument walki z biedą zagranica, a bardziej jako inwestycja w rozwój (o mniejszym znaczeniu komercyjnym) zarówno Japonii, jak i beneficjenta. Podobnie jak inni dawcy pomocy w tym czasie, rząd Japonii zakładał, że w ślad za zrównoważonym wzrostem będzie ostatecznie postępować ograniczenie biedy ${ }^{4}$.

Takie rozumienie pomocy miało później wpływ zarówno na zarządzanie pomoca, jak i na jej cele. Japonia zaczynała jako stosunkowo niewielki dawca - na poziomie $0,25 \%$ PKB w latach 60 . (wobec średniej dla innych członków DAC wynoszącej wówczas ok. 0,5 \% PKB). W 1977 r. rząd Japonii postawił sobie zadanie podwojenia programu ,współpracy ekonomicznej” w okresie 3-5 lat ${ }^{5}$. Miało to skutkować złagodzeniem nacisku USA na podział obciążeń (burden-sharing) oraz przywrócić wartość jena i ostatecznie przywrócić Japonii wiodącą rolę w sprawach dotyczących współpracy międzynarodowej i rozwoju. Już ok. 1989 r. Japonia stała się „supermocarstwem pomocowym” - największym indywidualnym dawcą pomocy w skali świata i pozycję tę utrzymała praktycznie przez większą część następnej dekady ${ }^{6}$. Rząd Japonii skoncentrował swoje wysiłki na celach rozwojowych. Główny akcent został jednak położony na działania związane z budową infrastruktury, a nie - jak to miało miejsce w wypadku innych krajów - na budowanie instytucji (institution building).

W związku ze wzrostem wartości pomocy zaczęto zwracać uwagę m.in. na brak transparentności i problemy korupcji, fragmentaryzację działań pomocowych (szczególnie w kwestii podejmowania decyzji) oraz brak ogólnej struktury pomocy. W 1992 r. przyjęta została przez rząd w Tokio „Karta Oficjalnej Pomocy Rozwojowej" (Official Development Assistance Charter) - pierwszy ważny dokument ustanawiający główne przesłanki i wytyczne dla dalszej aktywności w tej dziedzinie. Dokument potwierdzał, że Japonia prowadzi działania pomocowe nakierowane na walkę z biedą, wzmocnienie międzynarodowego współdziałania (interdependence), ochronę środowiska i dalsze wsparcie najsłabiej rozwiniętych krajów świata. Dodatkowo reforma japońskiej ODA i kierunki jej rozwoju dookreślone zostały w 1999 r. w innych dokumentach rządowych - w Średnioterminowej Po-

${ }^{4}$ Według danych DAC udział grantów w całości pomocy japońskiej (łącznie z pomocą multilateralną, która w całości jest pomocą w postaci grantu) wzrósł z nieco powyżej 50\% w $1993 \mathrm{r}$. do ponad 65\% w 2004 r. i około 80\% w 2007 r. W wypadku pozostałych krajów DAC traktowanych łącznie udział grantów w pomocy kształtuje się na poziomie $72 \%$. Pomoc bilateralna rządu Japonii stała się więc w większym stopniu pomocą preferencyjną niż pomoc DAC jako całości, [@:] http://stats. oecd.org/wbos/Index.aspx?DatasetCode=ODA_DONOR.

5 C. Lancaster, op.cit., s. 114-115.

${ }^{6}$ Ibidem, s. 110. 
lityce ODA oraz w krajowych programach pomocowych skierowanych do 10 największych odbiorców ${ }^{7}$. Pomoc japońska stopniowo coraz bardziej zbliżała się do norm DAC. Jednocześnie priorytetem nadal pozostawały raczej inwestycje w infrastrukturę (głównie ekonomiczna) i sprzęt (hardware) niż w transfer wiedzy (software), a rezultatem było raczej zwiększenie zysków niż wzmocnienie najbiedniejszego segmentu populacji w krajach-biorcach.

W końcu lat 90. wartość japońskiej pomocy zaczęła gwałtownie spadać, głównie ze względu na wewnętrzny kryzys ekonomiczny, a także z powodu skandali korupcyjnych związanych z jej realizacją. Rządowa pomoc bilateralna została skoncentrowana na projektach infrastrukturalnych, głównie w krajach Azji Wschodniej, co ostatecznie uczyniło z Japonii gracza niszowego, a nie światowego lidera pomocy.

W 2005 r. pomoc japońska kierowana była do 155 krajów i regionów:

45,6\% pomocy przypadało na Azję, 19,1\% trafiło do Afryki, 17,8 \% środków skierowanych zostało do Ameryki Łacińskiej, Środkowej i Północnej, 11,8\% funduszy finansowało projekty w rejonie Środkowego Wschodu, 3,8\% wydanych zostało w Oceanii, a jedynie 2,5\% w Europie.

Źródło: http://www.jica.go.jp/english/about/oda.html.

Dodatkowo na japońską pomoc wprost lub pośrednio wpływają trzy główne elementy. Po pierwsze - tradycja ,silnego państwa, słabego społeczeństwa”. Po drugie - próba realizacji obligatoryjnego nakazu pomocy biednym przez bogatych. Po trzecie - akcentowanie i realizacja wartości wzmacniających narodowy prestiż. Do tego dochodzi jeszcze jeden dodatkowy czynnik - prywatna filantropia nie należy do japońskiej tradycji, jak to ma miejsce w innych rozwiniętych krajach świata. Japońska pomoc zagraniczna tworzona była przede wszystkim jako narzędzie poprawy stosunków z USA (pośrednio) oraz z krajami strategicznie i ekonomicznie ważnymi dla Japonii (bezpośrednio), szczególnie w regionie Azji Wschodniej.

${ }^{7}$ Celem tych działań było zapewnienie jasnych i stabilnych reguł japońskiej ODA na najbliższe lata. Zob. Japan's Official Development 1999 (Summary), Japan, December 1999. 


\section{Historia bezzwrotnej pomocy japońskiej dla Polski}

Polska stała się beneficjentem japońskiej pomocy rozwojowej w 1989 r., kiedy to rząd w Tokio przygotował program na rzecz wsparcia dla polskiej transformacji w kierunku demokracji i gospodarki rynkowej, prowadzony w postaci pożyczek pomocowych i grantów (w tym na współpracę techniczną). Na spotkaniu Grupy G7 również inne najbogatsze państwa świata (Francja, Kanada, Niemcy, USA, Włochy oraz Wielka Brytania) podjęły decyzję o pomocy Polsce i innym krajom Europy Środkowo-Wschodniej, które rozpoczynały proces demokratyzacji i zmian gospodarczych. Organizacje międzynarodowe i rozwinięte kraje Zachodu, w tym Japonia, przeznaczyły określone zasoby finansowe na projekty i programy wdrażane w Polsce. Wśród nich były: program Phare, znaczące redukcje zadłużenia przez Klub Paryski i Londyński, programy wspierające transformację systemową prowadzone przez Bank Światowy oraz pomoc przedakcesyjna Unii Europejskiej.

Pierwszą pożyczkę o równowartości $134 \mathrm{mln}$ euro Polska otrzymała z Japonii w 1990 r. na utworzenie Funduszu Stabilizacji Walutowej. Inny znany przykład pomocy Japonii dla Polski stanowi nadzwyczajna pomoc żywnościowa w postaci grantu na zakup węgierskiej i amerykańskiej pszenicy w ramach Światowego Programu Żywnościowego w wysokości ok. 21,4 mln euro ${ }^{8}$. Przychód ze sprzedaży mąki na rynku wewnętrznym był wykorzystany, zgodnie z intencją rządu japońskiego, do utworzenia Funduszu Partnerskiego (Counterpart Funds - CPF). Uzyskane środki przeznaczone zostały na dodatkowe finansowanie przemian polskiej gospodarki, która po zmianie ustrojowej wymagała gruntownej reformy. Japonia skierowała również do Polski wsparcie w postaci grantów kulturalnych o równowartości $134 \mathrm{mln}$ euro, przeznaczonych na zakup sprzętu audiowizualnego i wyposażenia dla teatru, pomocy dla powodzian w 1997 r., a także pożyczki na zakup towarów udzielonej za pośrednictwem Międzynarodowego Funduszu Walutowego, która została wykorzystana na import wyposażenia do badań naukowych oraz aparatury medycznej. W sumie bezpośrednia pomoc Japonii dla Polski oszacowana została na kwotę ok. 220 mln euro.

Do 2007 r. rząd Japonii udzielał nam wsparcia przede wszystkim w formie pomocy technicznej, inwestycyjnej oraz transferów technologii. Finansowanie obejmowało projekty w różnych dziedzinach - od polityki finansowej, gospodarczej, przemysłowej i handlowej, poprzez szkolenia dla przedsiębiorców (głównie w za-

8 Jeśli nie zaznaczono inaczej, dane przytoczone zostały na podstawie materiałów udostępnionych przez Biuro JOCV i JICA w Warszawie oraz Ambasadę Japonii w Polsce, a także dokumenty UKIE, w tym notatki, sprawozdania i informacje urzędowe oraz raporty i wypowiedzi wolontariuszy japońskich i koordynatorów ich pracy w Polsce. 
kresie poprawy efektywności oraz zarządzania jakościa), projekty w dziedzinie ochrony środowiska, efektywności energetycznej, aż do prywatyzacji PKP, rozwoju regionalnego, edukacji, ochrony zdrowia itp. W większości przypadków inwestycjom w sprzęt towarzyszyły równoległe inwestycje w kwalifikacje i kompetencje kadr.

\begin{tabular}{l}
\hline Rodzaje bezzwrotnej pomocy japońskiej dla Polski: \\
bezzwrotna pomoc kulturalna -14 projektów, \\
projekty kulturalno-naukowe na małą skalę-3 projekty, \\
projekty zrealizowane z Polsko-Japońskiego Funduszu Partnerskie- \\
go-38 projektów.
\end{tabular}

Jednym z istotnych elementów japońskiego wsparcia była działalność wolontariuszy-specjalistów, kierowanych do Polski przez Organizację Japońskich Młodych Ekspertów ds. Współpracy z Zagranicą - Japan Overseas Cooperation Volunteers (JOCV).

Propozycja rozpoczęcia działalności wolontariuszy w naszym kraju padła oficjalnie w 1990 r., podczas wizyty ówczesnego premiera Japonii Toshiki Kaifu w Polsce. Oficjalny dokument programowy podpisany został w 1992 r. Program ruszył już w kilka miesięcy później - w lutym 1993 r. do Polski przyjechała „próbna grupa wolontariuszy krótkoterminowych" -2 specjalistów w dziedzinie języka japońskiego, 2 trenerów aikido oraz trener judo, a następnie pierwsza 7-osobowa grupa wolontariuszy długoterminowych (4 z nich uczyło języka japońskiego, a pozostali pracowali w projektach sportowych).

Współpraca polsko-japońska, realizowana w ramach bilateralnego programu pomocy rządu dla rządu, koordynowana była po stronie polskiej przez Biuro Pełnomocnika Rządu ds. Integracji Europejskiej oraz Pomocy Zagranicznej, a następnie (od 1996 r.) przez Urząd Komitetu Integracji Europejskiej. Bezpośrednią obsługę działań wolontariuszy prowadziło Biuro Koordynacji Kształcenia Kadr działające w ramach Fundacji „Fundusz Współpracy”. Po stronie japońskiej za działania wolontariuszy odpowiadało Biuro JICA/JOCV i Ambasada Japonii w Warszawie.

\section{Specyfika japońskiego wolontariatu}

Organizacja Japońskich Młodych Ekspertów ds. Współpracy z Zagranicą powstała w 1965 r. jako agencja japońskiego Ministerstwa Spraw Zagranicznych. Jej celem jest niesienie oficjalnej pomocy technicznej poza granicami kraju. Sekreta- 
riat JOCV stanowi strukturalną część Japońskiej Agencji Współpracy Międzynarodowej, a program JOCV jest jednym z głównych nurtów działalności Agencji. Od 1966 r. JOCV wydelegowała ponad 25 tys. młodych ekspertów do prawie 80 krajów świata - głównie Azji, Afryki, Ameryki Łacińskiej i Oceanii oraz od lat 90. do części postkomunistycznych krajów europejskich, w tym do Polski.

Przez cały ten czas wolontariat stopniowo zmieniał się i dostosowywał do nowych warunków. Wysłanie wolontariuszy do Europy Środkowo-Wschodniej, gdzie zakończył się okres zimnej wojny, stało się nowym etapem w jego rozwoju. Nastąpiło nie tylko poszerzenie obszaru działalności japońskich ochotników. Rozpoczęcie współpracy w regionie o specyficznej historii najnowszej i stosunkowo wysokich osiagnięciach technicznych stanowiło dla nich całkowicie nowe wyzwanie.

Działalność wolontariuszy traktowana jest przez rząd Japonii jako jeden z najskuteczniejszych sposobów promocji kraju i wzmocnienia jego pozytywnego wizerunku. Praca młodych ludzi w projektach w różnych regionach świata ma na celu bezpośrednie utrwalenie korzystnych konotacji związanych z osiagnięciami Japonii w wybranych obszarach, przede wszystkim takich jak sport, edukacja czy kultura, pobudza zainteresowanie krajem i popularyzuje wiedzę o nim. Praca wolontariuszy kierowana jest przede wszystkim (choć nie tylko) do młodzieży, czyli tej grupy, która będzie w niedalekiej przyszłości decydować o kierunkach rozwoju swojego kraju. Japończycy traktują działania młodych specjalistów jako długoterminową inwestycję, która w przyszłości może zwrócić się wielokrotnie. Przyjazd wolontariuszy do Polski był jedną z pierwszych japońskich misji tego typu w Europie.

W 1991 r. umowę o przyjęciu japońskich wolontariuszy podpisały Mongolia i Węgry. W 1992 r. do programu, oprócz Polski, przystąpiła Bułgaria. W 1994 r. do grupy beneficjentów dołączyły Wietnam oraz Rumunia. Od 1998 r., po podpisaniu umowy z Kirgizją i Uzbekistanem, rozpoczęła się współpraca z byłymi krajami Związku Radzieckiego, które uzyskały niepodległość.

Polska historycznie i społecznie zasadniczo różniła się od pozostałych krajów wcześniej objętych pomocą w ramach JOCV - m.in. poziomem techniki. Ze względu na znacznie wyższy poziom rozwoju od dotychczasowych beneficjentów pojawił się problem dostosowania form działalności do całkowicie odmiennych warunków. Tradycyjne metody współpracy zostały bowiem wypracowane i sprawdzone w warunkach krajów Trzeciego Świata - wyróżniających się nie tylko swoją specyfiką instytucjonalną i kulturową, ale także mających zupełnie inne oczekiwania. Istniała obawa, czy (i jaka) wiedza młodych Japończyków będzie przydatna 
w nowym kraju. Ostatecznie, po początkowych poszukiwaniach właściwej formuły, w Polsce skoncentrowano się nie na prostym przekazywaniu wiedzy i umiejętności, jak to miało miejsce we wcześniejszej praktyce, lecz na wzajemnej wymianie: podkreślono aspekt wzajemnego uczenia się od siebie.

W pierwszym okresie współpraca obejmowała głównie nauczanie języka japońskiego oraz sztuki walki. Z czasem spektrum kontaktów poszerzyło się o edukację (nauki ścisłe i przyrodnicze) oraz pomoc socjalną (rehabilitację, opiekę nad niepełnosprawnymi). Język japoński i sport pozostały jednak głównym nurtem współpracy w ramach wolontariatu, który został w ten sposób zdominowany w Polsce przez dziedziny o silnym elemencie wymiany kulturalnej. Strona japońska ustalała corocznie poprzez swoje Biuro JOCV w Warszawie zapotrzebowanie na japońskich ekspertów-woluntariuszy, zgłaszane przez krajowe instytucje i organizacje, w porozumieniu z polskim rządem, reprezentowanym przez Urząd Komitetu Integracji Europejskiej. JOCV organizował w Japonii nabór kandydatów dwa razy do roku i mniej więcej z taką częstotliwością przyjeżdżali oni później do Polski.

Zgodnie z japońskimi standardami, wolontariuszem mogła zostać osoba w przedziale wiekowym 20-39 lat. Czas delegowania był ustalony na dwa lata, z możliwością przedłużenia pobytu w uzasadnionych sytuacjach. Młodzi ochotnicy rekrutują się $\mathrm{z}$ różnych środowisk, przeważnie jednak pochodzą $\mathrm{z}$ małych miast, z fabryk. Uciekają przed bezrobociem, monotonią dorosłego życia, przewidywalnością ścieżek awansu zawodowego. Niektórzy przyjechali do Polski, ponieważ całe życie marzyli o podróżach i egzotyce. Inni byli tu po to, by robić to, co lubią. Wiele zaryzykowali - przebywanie za granicą nie uczyniło z nich dobrego materiału na pracownika: firmy japońskie najchętniej zatrudniają absolwentów, których łatwo ukształtować na potrzeby korporacji i wprowadzić do pracy w jednym przedsiębiorstwie na całe życie. Decyzja o wyjeździe łączyła się z rezygnacją z szansy na szybką karierę, ale dawała nadzieję na poszerzenie horyzontów i zmianę poglądy na świat ${ }^{9}$.

Przed przystapieniem do pracy w Polsce ochotnicy JOCV brali udział w szkoleniu, podczas którego uczyli się języka oraz poznawali kulturę kraju oddelegowania. W efekcie niektórzy po przyjeździe zupełnie nieźle radzili sobie z podstawowym słownictwem, polską składnią, a nawet $\mathrm{z}$ wymową całkowicie odmienną od ich języka ojczystego. Niejednokrotnie kontaktującym się z nimi Polakom nasuwało się pytanie, czy to zasługa metod kształcenia (w takim razie, w czym tkwi źródło tej skuteczności i czy metody te można przenieść do naszych warunków?),

${ }^{9}$ Niektórzy tak głęboko zakorzenili się w Polsce, że tu zostali - jedni, ponieważ znaleźli nowe rodziny, inni, aby kontynuować edukację za wcześniej zaoszczędzone pieniądze. Część z nich nadal kontynuuje misję rozpoczętą w ramach wolontariatu. 
czy też może pracowitości i dążenia do perfekcji, które stereotypowo przypisuje się Japończykom ${ }^{10}$ ?

\begin{tabular}{|l|}
\hline Senior volunteers \\
Japonia realizuje również od 1990 r. program wolontariatu oparty na \\
starszych kadrach ${ }^{11}$. Ochotnicy seniorzy to osoby w wieku od 40 do 69 \\
lat, posiadające specjalistyczną wiedzę w różnych dziedzinach (m.in. \\
takich jak: nowe technologie i przemysł, rolnictwo, kultura, transport, \\
sport) oraz wieloletnie doświadczenie w pracy nie tylko w sektorze \\
publicznym, ale przede wszystkim w sektorze prywatnym. Ich czas \\
oddelegowania (w tym do organizacji pozarządowych) wynosi zwy- \\
kle rok lub 2 lata. Pracują oni w szpitalach, szkołach, korporacjach \\
i NGOs, rzadziej natomiast w administracji rządowej. \\
W Polsce senior volunteers wspierali m.in. działania Biura JOCV/JICA \\
w Warszawie w zakresie koordynacji pracy i obsługi przebywających \\
u nas młodych specjalistów (ograniczenia finansowe nie pozwalały za- \\
trudnić stronie japońskiej dodatkowych osób). Wolontariusza seniora \\
zaprosiła też np. w 2002 r. Polsko-Japońska Wyższa Szkoła Technik \\
Komputerowych (PJWSK). Przebywał on w Warszawie 2 lata, a jego \\
podstawowym zajęciem było nauczanie języka japońskiego ${ }^{12}$.
\end{tabular}

${ }^{10}$ Jednocześnie nasuwała się refleksja, że w Polakach wyjeżdżających na staże i stypendia do Japonii, czasem wielomiesięczne, nie było japońskiej determinacji do maksymalizacji korzyści z takich pobytów. Zafascynowani możliwością egzotycznej podróży, koncentrowali się oni na materialno-bytowych warunkach staży, kierując wiele szczegółowych pytań na ten temat do instytucji pośredniczących w przygotowywaniu wyjazdów. Nie były natomiast zgłaszane oficjalne postulaty dodatkowego wsparcia dla stażystów i stypendystów w postaci np. podstawowego kursu języka japońskiego.

${ }_{11}$ Zob. JICA. INFO-KIT. File C-1 Senior Volunteer Programme of JICA, s. 3.

12 Jak pokazują dane JOCV, liczba starszych specjalistów wysyłanych z Japonii do różnych krajów świata szybko rośnie. W 1999 r. w ramach programu oddelegowanych zostało 87 osób, w 2000 r. było ich już 323, a w 2003 r. pracę podjęło 463 nowych ochotników. W 2003 r. grupa ta liczyła w sumie 1914 osób pracujących w 55 krajach. Zainteresowanie taką formą przedłużenia aktywności zawodowej osób w wieku najczęściej przedemerytalnym lub emerytalnym jest w Japonii znaczne. JICA sukcesywnie rozszerza swój program, [@:] http://www.jica.go.jp/english/schemes/citizen/volu.html.

Polska gościła stosunkowo niedużą grupę takich ekspertów. Nie stanowili oni jednak preferowanej grupy specjalistów dla beneficjentów pomocy. Doświadczenie pokazuje, że znacznie trudniej niż osobom młodym było im zaadaptować się do nowych warunków życia i pracy, jak również uzyskać akceptację środowisk, z którymi mieli współpracować. Mniej elastyczni i mniej otwarci, z dużym zasobem doświadczeń zawodowych, ale i bagażem doświadczeń życiowych częściej napotykali problemy w miejscach oddelegowania. 
Po przybyciu do naszego kraju kontynuowali oni przez 5 tygodni kurs języka polskiego w Szkole Języka Polskiego dla Cudzoziemców przy Uniwersytecie Łódzkim. Równocześnie mieszkali u polskiej rodziny, co pozwalało oswoić się im zarówno z nową kulturą, stylem życia, jak i z diametralnie odmienną, nierzadko trudną do zaakceptowania dla Azjaty kuchnią. W ten sposób szybciej przystosowywali się do nowych warunków, a także mieli okazję przełożyć teoretyczną znajomość polskiego na umiejętność komunikowania się.

Zachętą do starań o japońskich ekspertów były stosunkowo nieskomplikowane, a nawet przyjazne procedury. Po powszechnie znanych i szeroko dyskutowanych (choć nierzadko przesadzonych) problemach z przygotowywaniem dokumentów merytorycznych i finansowych, towarzyszących przyjazdom ekspertów unijnych, krótkie polskojęzyczne kwestionariusze zapotrzebowania na wolontariuszy od pierwszego kontaktu nastawiały przychylnie do japońskiego donatora (choć pozostawał problem wspólny dla większości programów pomocowych - długi, siegający nawet 2 lat, okres oczekiwania na decyzję rządu Japonii) ${ }^{13}$. Tak zwane zgłoszenie o oddelegowanie wolontariusza kierowane było do Biura JOCV w Warszawie. Organizacja wnioskująca musiała przygotować ogólną charakterystykę swojej struktury, opisać zadania i zrealizowane działania, określić wielkość rocznego budżetu, opisać dotychczasową współpracę międzynarodową. Kluczowe dla donatora było uzasadnienie potrzeby zaproszenia specjalisty oraz określenie celów, jakie powinny zostać osiagnięte dzięki jego pomocy. Oczekiwano również sprecyzowania, jakie stanowisko będzie zajmował ekspert oraz dokładnego opisu pracy, jaką miał wykonywać. Stronę japońską interesowały również kwestie techniczne współpracy, dodatkowe pytania dotyczyły m.in. sprzętu, jaki zostanie oddany do dyspozycji wolontariusza, charakterystyki otoczenia, z którym będzie miał kontakty, współpracowników, a także poziomu doświadczenia zawodowego osób, z którymi miał pracować (np. czy grupą docelową będą przede wszystkim dzieci i młodzież w wieku szkolnym, czy też wykładowcy, rolnicy, urzędnicy itp.). Japończycy interesowali się również warunkami funkcjonowania w Polsce

${ }^{13} \mathrm{~W}$ pomocy bilateralnej rządu Japonii obowiązuje stała ścieżka pozyskiwania wsparcia: wystąpienie przez rząd kraju-biorcy o grant do rządu Japonii, następnie faza badania projektu w Tokio pod względem określonych kryteriów (m.in. miejsce w hierarchii potrzeb rozwojowych, wkład w stabilizację i poprawę dobrobytu, preferencje raczej dla sektora publicznego (public benefits) niż finansowego czy gospodarczego (financial or economic benefits), możliwości zrealizowania projektu ze środków własnych lub pożyczek, perspektywy wykorzystania możliwości projektu) i w końcu faza implementacji, ewaluacji i ewentualnej kontynuacji działań projektu. W wypadku systemu wysyłania wolontariuszy w procesie decyzyjnym bardzo istotną rolę odgrywają ambasady (w wypadku Polski - Ambasada Japonii w Warszawie), Biura JICA w kraju wnioskującym o specjalistę (takie Biuro do końca maja 2008 r. miała również Polska) oraz Centrala JICA w Tokio, w ramach której działa również Sekretariat JOCV. Zob. JICA. INFO-KIT. File D-5 Grant Aid, s. 3. oraz JICA. INFO-KIT. File C-1 Senior Volunteer Programme of JICA, s. 3. 
zaproszonego specjalisty - możliwościami przemieszczania się i komunikowania (połączenia, odpłatność itp.), długością urlopu, godzinami pracy itp. JOCV prosiła także o sformułowanie oczekiwań strony przyjmującej - o określenie dziedziny, w jakiej powinien specjalizować się wolontariusz, najbardziej dogodnego terminu rozpoczęcia pracy, minimalnych oczekiwań w zakresie wykształcenia i doświadczenia zawodowego, dodatkowych pożądanych kwalifikacji, w tym języka, jaki powinien znać wolontariusz. Ankieta kierowana do organizacji wnioskującej dotyczyła też warunków, jakie gwarantowała strona zapraszająca: rodzaju i kosztów zakwaterowania, połączenia z Warszawa, opieki medycznej ${ }^{14}$.

Warto przy tym zaznaczyć, że Tokio nie oczekiwało stworzenia wolontariuszom specjalnych warunków pobytu; wręcz przeciwnie - zakładano, iż powinni oni żyć i pracować tak jak mieszkańcy przyjmujących ich miejscowości. Miało to pozwolić ochotnikom łatwiej zrozumieć lokalne problemy, nawiązać kontakty i podjąć współpracę w nowym środowisku. W rezultacie młodzi Japończycy zazwyczaj byli postrzegani jako ,prawie swoi”, nie tworzył się dystans charakterystyczny dla wielu ekspertów i doradców z krajów kulturowo bliższych Polsce.

\section{Japońscy młodzi specjaliści w Polsce}

W latach 1993-2007 pracowało w Polsce w sumie 106 młodych wolontariuszy. Ok. 30\% z nich stanowili nauczyciele języka japońskiego (36 osób), ok. 40\% to byli instruktorzy sportowi, specjalizujący się w baseballu, judo, aikido, karate, kendo itp. (44 osoby). Pozostali zajmowali się szeroko rozumianą działalnością edukacyjną (matematyka, chemia, praca z młodzieżą, sztuki piękne, ochrona zabytków i in. - 13 osób), a także pomocą społeczną (5 osób). Większość z Japończyków przyjechała do Polski na kontrakty dwuletnie ${ }^{15}$. Niektórzy z nich przedłużyli pobyt, najczęściej o rok. Zdarzały się również wypadki powrotów na kolejny okres

${ }^{14}$ W kwestionariuszu znalazło się m.in. pytanie o dostęp do elektryczności. W wypadku japońskiego wolontariatu, tak jak w wypadku wielu innych programów pomocowych, darczyńcy mają uniwersalne formularze, pytania, zagadnienia do wyjaśnienia, niezależnie od poziomu rozwoju kraju, do którego kierowane jest wsparcie. Polska nie należy do tej grupy krajów, gdzie dostęp do elektryczności stanowi problem, ale obsługująca japoński program centrala w Tokio pozostała przy standardowych zapytaniach.

15 Tzw. regularni wolontariusze stanowili wśród nich grupę najliczniejszą - 93 osoby. Na krótkie pobyty w Polsce przyjechało jedynie 6 osób. Pracę wolontariuszy wspierało w sumie 8 koordynatorów. Ostatnia 3-osobowa grupa współpracowników JOCV została wysłana do Warszawy w listopadzie 2005 r. Wolontariuszy z Japonii nie oddelegowano również w 2003 r., tj. w roku referendum akcesyjnego. Strona japońska nie miała bowiem jeszcze w tym czasie ostatecznie dookreślonej polityki pomocowej wobec kraju wstępującego do Unii Europejskiej, tj. do „klubu” najbogatszych krajów Europy. Początkowo planowano zakończenie programu od momentu członkostwa. Ostatecznie, 
pracy (rekordzistka spędziła w Polsce 6 lat, przyjeżdżając trzykrotnie - w 1999 r., 2002 r. oraz 2005 r.).

Tablica 1

Obecność wolontariuszy w Polsce w poszczególnych latach

\begin{tabular}{|c|c|c|c|c|c|}
\hline Rok & $\begin{array}{c}\text { Liczba wolonta- } \\
\text { riuszy w Polsce }\end{array}$ & Rok & $\begin{array}{c}\text { Liczba wolonta- } \\
\text { riuszy w Polsce }\end{array}$ & Rok & $\begin{array}{c}\text { Liczba wolonta- } \\
\text { riuszy w Polsce }\end{array}$ \\
\hline 1993 & 11 & 1998 & 44 & 2003 & 86 \\
\hline 1994 & 18 & 1999 & 55 & 2004 & 91 \\
\hline 1995 & 24 & 2000 & 65 & 2005 & 98 \\
\hline 1996 & 30 & 2001 & 75 & 2006 & 98 \\
\hline 1997 & 35 & 2002 & 86 & 2007 & 98 \\
\hline
\end{tabular}

Źródło: Opracowanie własne na podstawie danych Ambasady Japonii w Warszawie.

Działalność JOCV prowadzona była w 30 miejscowościach. Ochotnicy uczyli języka japońskiego na zajęciach fakultatywnych w szkołach średnich Krakowa, Wrocławia, Łodzi, Gdańska, Nowego Targu, a także w ośrodkach akademickich: w Gdańsku - na Uniwersytecie Gdańskim oraz w Studium Języków Obcych, w Łodzi - na Politechnice Łódzkiej, w Poznaniu - na Uniwersytecie im. Adama Mickiewicza, w Toruniu - na Uniwersytecie Mikołaja Kopernika, w Warszawie w PJWSTK oraz w Prywatnej Wyższej Szkole Biznesu i Administracji. Ich praca nie ograniczała się jednak do dużych miast, ale obejmowała praktycznie całe terytorium Polski. Młodzi Japończycy pracowali m.in. w klubach sportowych, domach kultury, ośrodkach pomocy społecznej w takich ośrodkach jak Przemyśl, Jabłonna Lacka, Czaniec, Huwniki i inne.

Decyzje o wystapieniu o wolontariuszy na początku przyjmowane były często sceptyczne, szczególnie wśród społeczności małych miejscowości. Obecność „obcych”, ich udział w życiu szkoły czy gminy wydawał się do tego stopnia nienaturalny, że niepokojono się, iż trudności, z którymi borykały się różne struktury, będą narastać, a nie ustępować. Obawiano się problemów biurokratycznych, komunikacyjnych, nieraz z zażenowaniem wskazywano, że długoterminowi przybysze będą mieli możliwość przyglądania się temu, co się na ogół ukrywa przed turystami i krótkookresowymi gośćmi - nieporządkowi, chaosowi, w wielu wypadkach stosunkowo prymitywnemu jak na warunki europejskie wyposażeniu w infrastrukturę itp. Tym bardziej, że Japonia w mentalności Polaków funkcjonuje jako kraj

z uwagi na ogromne zainteresowanie polskich organizacji tą formą współpracy z Japonią, rząd w Tokio zdecydował o stopniowym wygaszaniu wolontariatu. 
bardzo wysoko rozwinięty, dostatni, z nowoczesną techniką i technologią, zamożnymi obywatelami regularnie podróżującymi po świecie itp.

Tablica 2

Rozkład terytorialny wolontariuszy przebywających w Polsce w okresie 1993-2007

\begin{tabular}{|l|l|l|c|l|l|l|l|}
\hline \multicolumn{7}{|c|}{ Miejscowość i liczba wolontariuszy } \\
\hline Bytom & 1 & Legionowo & 2 & Nowosolna & 3 & Rąbień & 1 \\
\hline Czaniec & 1 & Legnica & 1 & Nowy Targ & 2 & Świdnik & 1 \\
\hline Gdańsk & 8 & Lublin & 4 & Olsztyn & 1 & Świebodzin & 3 \\
\hline Huwniki & 1 & Łańcut & 1 & Opole & 1 & Toruń & 4 \\
\hline Jabłonna Lacka & 1 & Łódź & 10 & $\begin{array}{l}\text { Ostrowiec } \\
\text { Swiętokrzyski }\end{array}$ & 1 & Warszawa & 13 \\
\hline Jastrzębie Zdrój & 3 & Miejska Górka & 3 & Poznań & 4 & Wrocław & 8 \\
\hline Kraków & 4 & Moragg & 1 & Przemyśl & 2 & Zamość & 3 \\
\hline Kutno & 1 & Myślenice & 1 & Radom & 1 & Zwierzyniec & 1 \\
\hline
\end{tabular}

Źródło: Opracowanie własne na podstawie danych Ambasady Japonii w Warszawie.

\section{Odbiór wolontariuszy}

Wolontariusze byli najbardziej pożądani i najserdeczniej traktowani w małych miejscowościach. Tam pobyt Japończyków wywoływał zazwyczaj duże zainteresowanie i sympatię mieszkańców. Zakupy w sklepach, dojazdy autobusem, wycieczki rowerowe stawały się okazją do nawiązywania bliższych kontaktów. Mieszkańcy zapraszali ich do domów, zabierali na wycieczki, „tłumaczyli” Polskę.

Traktowali ich jak swoich i jednocześnie jak najlepszych gości. Po dwóch latach z żalem się z nimi żegnali. Byt jednym z mieszkańców naszej gminy do końca - tak wspominał pobyt japońskiego trenera prezydent Towarzystwa Sympatyków Baseballu w Miejskiej Górce.

Zazwyczaj, kiedy zbliżał się koniec pobytu jednego wolontariusza, już myślano o następnym. Przyzwyczajały się do nich lokalne władze, trenerzy, nauczyciele - jedni, ponieważ uatrakcyjniali ich miejscowość, inni, bo wspierali ich swoim doświadczeniem, pomysłowością, a także odciążali od części trudnych zadań.

Tymczasem wolontariusze nadzwyczaj szybko budowali dobre relacje ze środowiskiem, w którym przebywali. Ciekawość innej kultury wśród początkowo scep- 
tycznych współpracowników i mieszkańców, tradycyjna polska gościnność okazywały się silniejsze niż niechęć w stosunku do obcych. Przedstawiciel Zamościa tak opisał historię trójki japońskich ekspertów: Kiedy podjęliśmy decyzję o przyjęciu wolontariusza, wśród społeczności lokalnej podniosty się głosy sprzeciwu. Pytano nas, dlaczego to robimy. Wolontariusze przedstawiali kulture Japonii i zbudowali bardzo dobre relacje ze społecznościq lokalnq. Wszyscy mieszkańcy bardzo dziękuja za pobyt wolontariuszy. Młodzi Japończycy, skromni i zawsze uśmiechnięci (niezależnie od tego, że uśmiech w kulturze Azjatów mniej zależy od dobrego nastroju, a bardziej jest przejawem grzeczności), szybko zjednywali sobie przychylność. Początkowo zdziwienie, a później szacunek wzbudzało ich zaangażowanie w rozwiązywanie lokalnych problemów. Podziwiano ich za to, że byli cały czas „obecni”, że żyli, jedli i spędzali wolny czas wśród ludzi, z którymi pracowali, że nie izolowali się ,po zajęciach”, nie tworzyli własnych enklaw, jak często czynią cudzoziemcy w obcym środowisku. Po pracy "etatowej", po zajęciach w szkole czy w klubie, chętnie angażowali się w zajęcia dodatkowe, nieprzewidziane w zakresie obowiązków: prowadzili dla zainteresowanych kursy parzenia herbaty i origa$m i^{16}$, uczyli kaligrafii, z ogromnym zaangażowaniem przybliżali kulturę i zwyczaje swojego kraju (m.in. organizowali dni japońskie, prezentowali tradycyjne stroje, ikebanę, przybliżali idee Sembazuru ${ }^{17}$ ) itd. Brali także udział i sami organizowali konkursy oraz pokazy sztuk walki, jeździli ze swoimi uczniami na zawody sportowe po całej Polsce. Byli aktywni przez 7 dni w tygodniu, pomimo przysługujących im standardowych praw do przerw w pracy i urlopu ${ }^{18}$.

Życie wolontariuszy w Polsce nie obywało się bez problemów. Dotknęły ich nie tylko kradzieże i chuligańskie pobicia. Najbardziej powszechnym doświadczeniem była nietolerancja. Wspominali z zażenowaniem wyśmiewających ich na ulicy przechodniów, wyrostki przedrzeźniające język, ostentacyjnie oglądających się na ich widok i przyglądających się im dorosłych (nie tylko w prowincjonalnym Ostrowcu Świętokrzyskim, ale także w dużych miastach, a nawet w wydawałoby się otwartych na zmiany ośrodkach akademickich, takich jak Łódź czy Wrocław, a nawet w ,światowym” Zakopanem). Nie w każdej placówce czekali też życzliwi współpracownicy i uzgodnione wcześniej obowiązki. Kilkoro z nich, dla dobra obu stron, musiało nawet zmienić miejsce pobytu i pracy. Japończycy zwracali uwagę, że Polacy dumnie uważają się za naród tolerancyjny, jednak nie potwierdzają

16 Pochodząca z Chin, rozwinięta w Japonii sztuka składania papieru.

17 Papierowe żurawie będące symbolami pokoju.

18 To głównie dzięki ich pracy rozwinęła się np. wieloletnia polsko-japońska współpraca w dziedzinie baseballu. Japońscy trenerzy tego sportu rozpoczęli współpracę z Akademią Wychowania Fizycznego we Wrocławiu i klubami baseballu w Jastrzębiu Zdroju, a ich wychowankowie zaczęli odnosić znaczące sukcesy. Wolontariusze JOCV pracowali później także w klubach w Kutnie i Miejskiej Górce. 
tego swoim zachowaniem. Co więcej, usprawiedliwiają się, twierdząc, że dyskryminacja występuje wszędzie, można zatem uznać taki stan za normalny, a Polska nie odbiega od standardów. Tylko, jak zauważali wolontariusze, gdzie indziej zauważa się problem i rozmawia się o nim, w Polsce natomiast zmienia się temat rozmowy; a bez dyskusji nie będzie zmiany. Ich zdaniem, Polakom potrzebne są regularne zajęcia o skutkach i przyczynach rasizmu w szkołach, inaczej problem może się nasilać. Należy przy tym podkreślić, że nietolerancja wobec wolontariuszy nie występowała incydentalnie; tak wyglądała ich codzienność.

Pomimo tych trudności młodzi ochotnicy nie rezygnowali z pobytu w Polsce. Równie chętnie pracowali w dużych miastach, jak i niewielkich miasteczkach ${ }^{19}$. Dzięki nim nawet młodzież z bardzo małych ośrodków miała okazję zapoznać się z japońską kulturą i sztukami walki Dalekiego Wschodu bezpośrednio od japońskich specjalistów i ekspertów. Pobyt wolontariuszy w szkołach był niepowtarzalną szansą dla uczniów, nauczycieli, członków lokalnej wspólnoty do zdobycia informacji na temat kultury, sztuki, położenia geograficznego, klimatu, elementów historii i tradycji dalekiego i egzotycznego kraju. Zajęcia sportowe (judo, aikido, baseball itp.) stanowiły atrakcyjną formę pozalekcyjnej aktywności fizycznej, poszerzającą często mało urozmaiconą ofertę zajęć prowadzonych w szkołach. Sale gimnastyczne były w końcu dostępne poza godzinami pracy placówek, również w soboty, lepiej wykorzystywany był posiadany sprzęt sportowy ${ }^{20}$, a całe rodziny (na zajęcia treningowe przychodzili nierzadko wspólnie rodzice i dzieci) miały możliwość atrakcyjnego spędzania czasu wolnego pod opieką wykwalifikowanego wychowawcy/trenera. W ośrodkach, gdzie dzieci i młodzież nie mają do wyboru zbyt wielu atrakcji, a ogólna niechęć do szkolnych zajęć sportowych jest taka sama jak w większości polskich szkół, sytuacja, gdy uczniowie sami dopominali się o dodatkowe zajęcia w sali gimnastycznej budziła najpierw zdumienie, a potem prowokowała zwiększoną aktywność polskich nauczycieli, którzy wspierali wolontariuszy w podtrzymywaniu nowego zapału.

Pobyt Japończyków w szkołach, w klubach, na uczelniach przyczynił się także do popularyzacji samego wolontariatu, który w Polsce wciąż pozostaje nową

19 Dzięki staraniom wójta gminy Nowosolna k. Łodzi zapoczątkowano sprowadzanie wolontariuszy również do pracy z młodzieżą wiejską (nauczyciel wychowania fizycznego). Z biegiem czasu inicjatywa ta bardzo się rozszerzyła, skorzystali z niej m.in. mieszkańcy Świebodzina, Nowosolnej, Miłoradza.

${ }^{20}$ W niektórych ośrodkach obecność wolontariuszy zaprocentowała dodatkowo dostawami najbardziej niezbędnego wyposażenia. Młodzi Japończycy, widząc mizerię finansową klubów sportowych, szczególnie szkolnych, czynili nadludzkie wprost wysiłki, aby ściągnąć dla swoich podopiecznych dodatkowe piłki, stroje treningowe, maty itp. Przedmioty te pochodziły z Japonii, z ośrodków zaprzyjaźnionych z japońskimi specjalistami, i choć nie były nowe, okazywały się w polskich warunkach niezastapione. 
i mało znaną formą aktywności. Młodzież miała okazję zetknąć się z konkretnymi przykładami bezinteresownej pracy, którą można prowadzić zarówno dla potrzebujących z „dalekiego kraju”, jak i na rzecz swojego najbliższego otoczenia.

Notatka z internetowego pisma lokalnego „Kronika Tygodnia” na te-
mat pracy wolontariuszki z Zamościa.
Poznaj Japonię. Sakie Hiyoshi - wolontariuszka z Japonii - 25 paź-
dziernika będzie gościem spotkania organizowanego przez Młodzieżo-
wy Dom Kultury im. K. Makuszyńskiego w Zamościu, w ramach cyklu
„Znani i podziwiani”. Najpierw zostanie wyświetlony film o Hiroszi-
mie. Później zaplanowano prezentację wystawy plakatów o Japonii. Sa-
kie pokaże m.in. japońskie kimono i zademonstruje jak się robi origami.
Sakie Hiyoshi przyjechała do Polski na zaproszenie wójta gminy Za-
mość. W Zespole Szkół w Wysokiem prowadzi Klub Japoński dla dzie-
ci i młodzieży. Uczy japońskiego alfabetu, pisowni i prowadzi warsz-
taty składania papieru „Origami”.
Zob. www.kronikatygodnia.pl/tekst.php?abcd=20498\&dz=3\#gora.
Data publikacji: 23.20.2007r.

Podczas trwania wolontariatu szkoły odwiedziło wielu gości z Japonii, włączając $w$ to przedstawicieli Ambasady Japonii w Warszawie. Uczniowie często po raz pierwszy mieli okazję bezpośrednio zetknąć z obcokrajowcami, wypróbować w praktyce i uzmysłowić sobie potrzebę umiejętności posługiwania się innymi językami. W środowisku wiejskim, gdzie możliwości spędzania czasu wolnego przez młodzież są ograniczone, dodatkowa pozalekcyjna oferta zajęć spotykała się z bardzo pozytywnym odzewem zarówno uczniów, jak i ich rodziców. Obecność wolontariuszy powodowała dodatkową uwagę i przychylność władz gminnych i instytucji kultury, w przedsięwzięcia przez nich inicjowane chętnie angażowali się także sami mieszkańcy. Obecność obcych mobilizowała do działania, prowokowała starania o nowe wyposażenie oraz środki na dodatkowe zakupy materiałów i sprzętu (papier do origami, sprzęt fotograficzny do dokumentowania pobytu japońskich gości, siatki do treningów sportowych itd.).

Przyjazd wolontariuszy z Japonii wymagał współdziałania samorządowców, nauczycieli, uczniów, dyrektorów szkół i innych pracowników. Współpraca była bardzo ścisła z uwagi na różnorodność i mnogość spraw związanych z pobytem obcokrajowców. Uczono się prawidłowego przekazu informacji, kompromisu i zaangażowania w działania społeczne. Z kolei udział Japończyków w różnych imprezach szkolnych i gminnych, ich szerokie kontakty oraz współpraca z różnymi ośrodkami przekładały się na postępowanie władz i społeczności lokalnych. Wo- 
lontariusze na ogół zdobywali sympatię i wywoływali zaciekawienie, poznawali w związku z tym wiele osób, które akceptowały ich jako ekspertów, ale także jako miłych i sympatycznych ludzi - i w związku z tym starały się wesprzeć ich w pracy, a to przynosiło bezpośrednie korzyści ich podopiecznym. Podczas realizacji programu pobytu wolontariuszy rozwijała się też z reguły współpraca z lokalnymi mediami (prasa, radio). Przy okazji intensywnie promowano kluby, szkoły, miejscowości. Wyniki okazały się trwałe, a nabyte umiejętności współpracy są nadal wykorzystywane w wielu sytuacjach.

\begin{tabular}{|l|}
\hline Kontynuacja współpracy \\
Po wyjeździe japońskich wolontariuszy młodzi Polacy długo utrzymy- \\
wali z nimi kontakty. Przez wiele miesięcy uczniowie i nauczyciele \\
opisywali, co nowego zdarzyło się w szkole. W rezultacie wolontariusz \\
z Zespołu Szkół w Wysokiem z własnej inicjatywy na święta Boże- \\
go Narodzenia w 2005 r. przysłał do szkoły paczkę z zabawkami dla \\
przedszkolaków - zabawki były darem uczennic z prowadzonej przez \\
niego klasy liceum w Tokio, gdzie opowiadał o swojej pracy w egzo- \\
tycznej Polsce. Wraz ze współpracownikami Technikum Handlowe- \\
go stworzył też klub Sympatyków Wolontariatu Międzynarodowego, \\
do którego zaprosił również polską młodzież. W ramach wzajemnych \\
kontaktów zainicjowane zostały internetowe rozmowy z dziećmi, co \\
pozwoliło obu stronom praktycznie uczyć się wzajemnego rozumienia \\
odmienności narodowych i otwierania się na inną kulturę.
\end{tabular}

Wolontariusze nie mogli się pogodzić z niezrozumiałym dla nich, a chwilami wręcz irytującym brakiem u Polaków entuzjazmu, determinacji i systematyczności w działaniu. Zajęcia, w które wkładali wszystkie swoje umiejętności i entuzjazm, szybko nudziły się i powszedniały. Z początkowych „nadkompletów” zainteresowanych pozostawały z czasem małe grupki. Pracę dezorganizowały spóźnienia, brak koncentracji, częste nieobecności. Japończycy, sami obowiązkowi, nie mogli się pogodzić z jedynie chwilowym zapałem oddanych pod ich opiekę dzieci i młodzieży. Niektórzy narzekali też niejednokrotnie na trudne stosunki międzyludzkie.

Większość japońskich ochotników przy wykonywaniu swoich zadań wchodziła w rolę wychowawców - w sporcie, w trakcie nauki języka, przy prezentowaniu zwyczajów swojego kraju. Ćwicząc aikido, uczyli polskich adeptów obcowania z kulturą japońską, odwoływali się do etykiety związanej ze sztuką walki, ale przywoływali także szersze konteksty codziennego życia i stosunków międzyludzkich. Prezes Legnickiego Klubu Karate wspominał: Podczas zajęć sportowych nie ograniczali się do prostego treningu fizycznego i treningu umiejętności - wzorowali się 
sami i przekazywali swoim uczniom japońskie cechy narodowe wzięte z Kodeksu Bushido. Honor, lojalność, poświęcenie w ich wykonaniu to nie byty same słowa. Od wolontariuszy nie tylko uczniowie wiele się nauczyli. Polskim nauczycielom i trenerom też udzielał się ich zapał; chętnie korzystali z możliwości podpatrywania, przedyskutowania i przećwiczenia innych sposobów prowadzenia zajęć, metod wychowawczych, wzorców itd. Równocześnie obie strony wzajemnie uczyły się tolerancji i poszanowania różnic. Wspólne działania pozwalały przekonać się, jak ważne jest odczuwanie i akceptowanie odmienności, bezpośrednie doświadczenie faktu istnienia innych kultur i sposobów myślenia.

Nie oznacza to, że nie dochodziło do spięć i konfliktów. Wielokrotnie sygnalizowano np., że „,nadaktywność” cudzoziemców nie służy budowaniu autorytetu miejscowych nauczycieli i trenerów. Ci ostatni, w przeciwieństwie do wolontariuszy, oprócz pracy zawodowej mieli jeszcze inne obowiązki. Nie byli więc w stanie konkurować z Japończykami ilością czasu poświęcanego swoim podopiecznym, a co za tym idzie i efektami, jakie ostatecznie osiagali.

Dzięki wolontariuszom w kilku szkołach średnich na terenie całego kraju jako dodatkowy trzeci język pojawił się egzotyczny w Polsce japoński. Wielu maturzystów pod wpływem spotkania z młodymi specjalistami z Japonii wybierało później studia japonistyczne, a uczniowie liceów i studenci japonistyki potwierdzali swoją znajomość języka w konkursach krasomówczych organizowanych corocznie przez Ambasadę Japonii ${ }^{21}$. Początkowo wydawało się to dosyć zaskakujące, ale jest dodatkowym świadectwem zmian, jakie zaszły w naszym kraju w ostatnich latach, w tym otwarcia na świat i wiążącego się z tym wzrostu zainteresowania kulturą innych narodów, wzrastającą liczbą japońskich turystów i japońskich biznesmenów, nowymi, praktycznie nieograniczonymi możliwościami pracy i studiowania, również w Azji. Pochodną tych procesów jest właśnie zainteresowanie kulturą i gospodarką, w tym nauką języka, w dobie globalizacji szczególnie ułatwiającego nawiązywanie kontaktów i komunikowanie się. Odnosząc te zjawiska do pracy wolontariuszy, warto zauważyć, że głównie dzięki nim język japoński zaczął być postrzegany jako atrakcyjny przez zafascynowaną przede wszystkim angielskim młodzież szkolną.

Aktywność wolontariuszy odnosiła się jednak nie tylko do sportu i edukacji. Eksperci JOCV pracowali także w muzeach w Krakowie i w Łodzi, gdzie pomagali w nawiązywaniu kontaktów ze specjalistami w Japonii, uczestniczyli w organizowaniu wystaw, katalogowali dzieła sztuki z wykorzystaniem najnowszej techniki komputerowej. Pomagali w domach kultury - w Domu Kultury w Myślenicach

${ }^{21}$ W 2003 r. uznano poziom nauczania języka japońskiego i kwalifikacje polskich specjalistów za tak wysokie, że strona japońska wstrzymała przysyłanie nauczycieli języka japońskiego. Od 2004 r. w Warszawie można zdawać oficjalny egzamin z języka japońskiego. 
ochotnik uczył młodych ludzi m.in. podstaw japońskich technik malarstwa i rysunku. Rehabilitanci - wolontariusze pracowali nie tylko stosując najnowsze metody kuracji, ale korzystali także z tradycji japońskiej - m. in. trening sprawności manualnej prowadzili poprzez sztukę origami.

Ale obecność wolontariuszy pozostawiła po sobie również problemy. Przyzwyczajeni do japońskich specjalistów zawodnicy z trudem godzą się na zastąpienie ich polskimi trenerami. Spada gwałtownie zainteresowanie kulturą japońską, odkąd przestali ją prezentować japońscy ochotnicy. Przykładowo, Centrum Kultury Japońskiej w Przemyślu odnotowało znaczny spadek zainteresowania kursami ikebany, kaligrafii czy języka japońskiego, odkąd w regionie zabrakło wolontariuszy. Miejscowi instruktorzy nie stanowią już wielkiej atrakcji dla mieszkańców - nie są ani tak niezwykli, ani tak wiarygodni w tym, co robią i opisują. Podobne sytuacje miały miejsce $\mathrm{w}$ wielu innych miejscowościach - zajęcia z wolontariuszami cieszyły się zawsze znacznie większym powodzeniem, czy to w wypadku języka, czy sportu. Stanowisko samych wolontariuszy wyartykułował trener baseballu z Miejskiej Górki, który marzy, aby przyjechać za 20 lat do Polski i zobaczyć jak graja i trenuja zawodnicy, których miałem. Innego rozwoju sytuacji Japończycy prawdopodobnie nie przewidywali.

\begin{tabular}{|l|}
\hline Nauka „polskiego” \\
Młodzi japońscy eksperci imponowali determinacją, z jaką oswajali \\
naszą kulturę. Życzliwe rozbawienie wzbudzały ich próby zaakcepto- \\
wania polskiej wymowy, podobnie jak polskiej kuchni. Zdarzały się \\
osoby, które po 2 latach wyjeżdżały z Polski niemal swobodnie posłu- \\
gując się językiem polskim (niektórzy skarżyli się, że poznaliby pol- \\
ski jeszcze lepiej, ale Polacy woleli z nimi rozmawiać po angielsku); \\
większość z lubością wspominała bigos i schabowy; za to wszyscy bez \\
wyjątku na wspomnienie kaszanki oraz ryżu z truskawkami i ze śmie- \\
taną nieodmiennie demonstrowali gesty obrzydzenia.
\end{tabular}

Japońscy wolontariusze rzadko narzekali na warunki pracy i na warunki bytowe (jedna ze skarg dotyczyła, nieoczekiwanie, pobytu wolontariusza w Warszawie). Zwracali natomiast uwagę, że JOCV wysyła wolontariuszy do biednych krajów, a Polsce, w ich ocenie, taka pomoc nie jest potrzebna. Stopień przygotowania naszej kadry (np. w obszarze języka japońskiego), szczególnie w Warszawie, czyni sprowadzanie ekspertów z Japonii procesem co najmniej wątpliwym. Pomoc, podkreślali, jeśli w ogóle jest potrzebna, to tylko na prowincji - niektórzy wolon- 
tariusze, żeby pełnić swoją ,,misję”, przejeżdżali na własną prośbę do małych, oddalonych od centrum ośrodków ${ }^{22}$.

Cechą JOCV jest wzajemność doświadczeń. Wolontariusze wykorzystywali w Polsce swoją wiedzę ekspercką, a jednocześnie przybliżali Polakom japońską kulturę i język. Dzięki nim możliwe było poznanie Japonii innej niż funkcjonująca w stereotypach. Ale również strona przyjmująca miała jedyną w swoim rodzaju szansę na przedstawienie siebie. Japońscy ochotnicy byli nastawieni na poznanie. Dzięki współpracy z Polakami uczyli się języka, odkrywali kulturę, poznawali polski sposób myślenia. W rezultacie młodzi specjaliści, wyjeżdżając do Japonii, nie przestawali co prawda dziwić się dziurawym drogom i kierowcom nieprzestrzegającym przepisów, ale także podziwiali mosty na bardzo cienkich wspornikach niespotykanych w Japonii z powodu trzęsień ziemi, zachwycali się tonącą w zieleni architekturą miast, fascynowali przeszłością kraju, której wcześniej nie znali, interesowali przyszłością rolnictwa oraz wieloma innymi sprawami, o których wspominali w bezpośrednich rozmowach. Trener kendo z Wrocławia chwalił się w 2003 r.: Napisałem artykut dla japońskich gazet i czasopism, aby przedstawić rozwój kendo w Polsce. W 2007 r. ukazał się numer czasopisma wydawanego po japońsku przez JICA, poświęcony m.in. Polsce. Efekty pobytu wolontariuszy potwierdziły, że wolontariat z jednej strony stanowi skuteczny sposób niesienia wsparcia zewnętrznego, z drugiej zaś jest elementem promocji własnych najlepszych praktyk i doświadczeń.

\section{Nowy etap współpracy polsko-japońskiej}

Po wejściu Polski do Unii Europejskiej rozpoczął się nowy etap współpracy między dotychczasowym dawcą i biorcą pomocy rozwojowej. Sytuacja, że kraj przyjmujący pomoc sam zaczął udzielać wsparcia zdarzyła się pierwszy raz w ponad 40-letniej historii Japońskiej Organizacji Współpracy Międzynarodowej. Polska administracja w szczególności, ale także organizacje pozarządowe i środowiska akademickie przez cały okres transformacji współpracowały z Japonią oraz z innymi partnerami zagranicznymi. Na podstawie tych doświadczeń rozwija się

${ }^{22}$ Pracująca w okolicach Przemyśla fizjoterapeutka zauważyła w 2003 r., że rehabilitacja w Polsce jest prowadzona przestarzałymi metodami i znajduje się na bardzo niskim poziomie. Wykorzystywany jest stary sprzęt, a zabiegi nie obejmują ludzi leżących. Szokowało ją, że pracownicy niewłaściwie wywiązują się ze swoich obowiązków i źle się odnoszą do podopiecznych. Jednocześnie odnotowywała bardzo trudne warunki mieszkaniowe i życia codziennego Polaków, wśród których przebywała. Wskazywała także m.in. na brak dbałości o własne zdrowie oraz złe nawyki żywieniowe: Polskie jedzenie jest tluste, bardzo słodkie i dlatego dużo osób choruje na cukrzycę i otyłość. 
obecnie program polskiej pomocy rozwojowej, koordynowany przez Ministerstwo Spraw Zagranicznych.

Strona japońska uznała nową rolę Polski we współpracy międzynarodowej. Rząd Japonii i rząd RP (we współpracy z UNDP ${ }^{23}$ ) rozpoczęły w 2004 r. realizację 3-letniego projektu „kształcenia na odległość” dla Ukrainy. Uczestniczy w nim również PJWSTK, która powstała w 1994 r. z funduszy rządu japońskiego, przekazanych w ramach programu pomocy na rzecz rozwoju. PJWSTK odpowiada teraz za zorganizowanie na Ukrainie ośrodków kształcenia przez Internet, w projekcie wykorzystującym środki pochodzące z ODA - tym razem pomocy japońskiej i polskiej. Podobne wspólne działania planowane są również w innych częściach świata.

Jednym z elementów szerszego włączania się Polski w działania światowej pomocy rozwojowej jest także wolontariat. Obecność japońskich ochotników w szkołach, w klubach, na uczelniach w znaczący sposób przyczyniła się do popularyzacji tej wciąż w Polsce stosunkowo mało znanej formy pomocy międzynarodowej. Młodzież nierzadko po raz pierwszy miała okazję zetknąć się z konkretnymi przykładami wsparcia, które można prowadzić na rzecz potrzebujących z innych krajów. Japończycy pokazali, że wolontariat ma sens. Na podstawie doświadczeń zdobytych m.in. podczas misji japońskich w Polsce, a także szerszych doświadczeń japońskich z pracy w innych krajach powstaje, przygotowywana we współpracy z rządem w Tokio, polska odmiana organizacji młodych wolontariuszy pracujacych za granica. Opracowany przez polskie Ministerstwo Spraw Zagranicznych program staje się jednym z integralnych elementów polskiej pomocy zagranicznej ${ }^{24}$. Polska tworzy własny zintegrowany system wolontariatu „Polish Aid”, bazujący na organizacjach pozarządowych wspieranych centralnie przez instytucje rządowe. W lipcu 2007 r. w Japonii przebywała grupa studyjna, która zapoznała się z najlepszymi praktykami Centrum Szkolenia Wolontariuszy w Komagane. To m.in. Japończycy udowodnili w Polsce, że w dobie postępującej globalizacji wolontariat może stanowić sposób niesienia pomocy, ale także pożyteczną formę poznawania i uczenia się różnych kultur i krajów świata.

${ }^{23}$ Program Narodów Zjednoczonych ds. Rozwoju, ang. United Nations Development Programme.

${ }^{24}$ Dokumenty strategiczne dotyczące najważniejszych założeń polskiej ODA znajdują się na stronie internetowej www.polskapomoc.gov.pl. 